\title{
Bifurkacja reżimów niedemokratycznych społeczeństw masowych. Casus Polski czasów Edwarda Gierka
}

https://doi.org/10.19195/1643-0328.30.6

Słowa kluczowe: bifurkacja, monistyczny system polityczny, repellor, Polska, Edward Gierek

\section{Wstęp}

Procesy rozpadu reżimów niedemokratycznych były do tej pory przedmiotem licznych badań, jednakże zazwyczaj dotyczyły one tylko jednego - ostatniego - etapu. Ten finalny moment rozkładu danego reżimu zwykle definiowany jest jako rewolucja (wymiana klasy rządzącej na inną) lub implozja (załamanie się systemu politycznego połączonego $\mathrm{z}$ transformacją klasy rządzącej). Czasami w literaturze wymienia się też pucz lub przewrót pałacowy. Jednakże $\mathrm{w}$ tych dwóch ostatnich przypadkach nie zmienia się reżim polityczny, a klasa panująca zachowuje swoją dominującą lub hegemonistyczną pozycję. O wiele mniej badań - choćby ze względu na trudności metodologiczne i mniejszą widowiskowość - poświęcono procesom doprowadzającym do ostatecznego momentu rozkładu danego reżimu, a więc rewolucji lub implozji.

Zazwyczaj wymienia się liczne przyczyny doprowadzające do rozkładu danego reżimu politycznego, czyli niemożliwości jego reprodukcji. W przypadku wielu z tych przyczyn udowodniono, że ich znaczenie nie jest ważne bądź ma ograniczony zakres stosowalności. Warto wymienić na przykład sfalsyfikowane ostatnio przekonanie o znaczeniu takich determinant ekonomicznych wybuchu rewolucji, jak kryzys gospodarczy, istotne pogorszenie się poziomu życia ludności czy dysproporcje w ramach indeksu zrównoważonego rozwoju1.

1 G.A. Leonov, E.V. Kudryashova, N.V. Kuznetsov, Modeling and Identification of the Tunisian Social System in 2011-2014: Bifurcation, Revolution, and Controlled Stabilization, „IFAC-PapersOnLine” 48, 2015, nr 11, s. 725-729. 
Część z tych przyczyn jest w rzeczywistości wyłącznie objawem o wiele głębszych i mniej widocznych procesów rozkładu danego systemu politycznego.

Enumerowanie rozmaitych przyczyn (nawet jeśli niektóre z nich faktycznie miałyby charakter determinujący rozpad systemu politycznego) nie może być traktowane jako uniwersalny i przekonujący sposób wyjaśniania rozkładu reżimów politycznych. Warto zatem rozwinąć niektóre założenia czwartej generacji teorii rewolucji ${ }^{2}$. Konieczne jest według mnie zastosowanie teorii dotyczącej dynamiki zmian niedemokratycznych reżimów politycznych epoki społeczeństw masowych. Taką teorię można stworzyć poprzez odpowiednie zmodyfikowanie i uzupełnienie modeli bifurkacji funkcjonujących w matematycznych teoriach systemów dynamicznych. Sam termin „bifurkacja” był w naukach społecznych stosowany już wielokrotnie, a najbardziej znanym przykładem są jego liczne użycia dokonane przez Immanuela Wallersteina, chociażby w opisach koncepcji systemu światowego ${ }^{3}$. Modele bifurkacji (na przykład Hopfa) były już wykorzystywane do analizy systemu partyjnego ${ }^{4}$, sytuacji Wielkiej Brytanii po referendum dotyczącym wyjścia $\mathrm{z} \mathrm{UE}^{5}$ oraz $\mathrm{w}$ wielu innych pracach politologicznych ${ }^{6}$.

\section{Teoria bifurkacji reżimów politycznych}

W dalszej części artykułu została przedstawiona propozycja nowatorska w porównaniu do dotychczasowej literatury. Jej nowatorskość dotyczy nie tylko odpowiedniego przekształcenia dostosowującego do potrzeb nauk społecznych podstawowych kategorii modeli bifurkacji (ang. saddle point, attractor itd.), lecz przede wszystkim stworzenia oryginalnej teorii na temat procesów bifurkacyjnych reżimów niedemokratycznych epoki społeczeństw masowych.

Przypuszczam, że prawidłowo zmodyfikowane matematyczne modele bifurkacji lokalnej (i z mniejszą pewnością - globalnej) mają znaczącą moc eksploracyjną dla wyjaśnienia przebiegu procesów rozpadu reżimów niedemokratycznych społeczeństw masowych. Konieczne jest w takim przypadku zdefiniowanie w języku nauk społecznych

2 J.A. Goldstone, Toward a Fourth Generation of Revolutionary Theory, „Annual Review of Political Science" 4, 2001, nr 1, s. 139-187.

${ }^{3}$ I. Wallerstein, World-System Analysis: Theoretical and Interpretative Issues, [w:] T.K. Hopkins, I. Wallerstein, World-System Analysis: Theory and Methodology, Beverly Hills 1982, s. 91-103; idem, The Modern World-System and Evolution, „Journal of World-Systems Research” 1, 1995, nr 1, s. 512-522; idem, The Time of Space and the Space of Time: The Future of Social Science, „Political Geography” 17, 1998, nr 1, s. 71-82.

${ }^{4}$ Q.J.A. Khan, Hopf Bifurcation in Multiparty Political Systems with Time Delay in Switching, „Applied Mathematics Letters" 13, 2000, nr 7, s. 43-52.

5 W. Jennings, G. Stoker, The Bifurcation of Politics: Two Englands, „The Political Quarterly” 87, 2016, nr 3, s. 372-382.

6 C. Seeds, Bifurcation Nation: Strategy in Contemporary American Punishment, 2015, https://papers. ssrn.com/sol3/papers.cfm?abstract_id=2613083 (dostęp: 10.03.2021); G.G. Rao, Hyderabad and the Bifurcation of Andhra Pradesh, „Economic \& Political Weekly” 2013, nr 48 (42), s. 34-41; B.C. Schmidt, Political Discourse of Anarchy: A Disciplinary History of International Relations, New York 2016. 
kluczowych typów modeli bifurkacyjnych. Należy w związku z tym zastanowić się nad stosowalnością bifurkacji: lokalnej (na przykład Saddle-node (fold), Transcritical, Pitchfork, Period-doubling (flip), Hopf i Neimark-Sacker) oraz globalnej (Homoclinic, Heteroclinic, Infinite-period oraz Blue sky catastrophe) ${ }^{7}$. Warto też rozważyć próbę stworzenia nowych typów bifurkacji lokalnej i globalnej.

Niezbędne jest też adekwatne zdefiniowanie podstawowych pojęć teorii bifurkacji. Punkt siodłowy (saddle point) to moment przejścia od stanu trwałego equilibrium do coraz większego poziomu niestabilności. Można w tym przypadku mówić o chwiejnym equilibrium. Czynnikiem dezintegrującym (repellor) jest przede wszystkim zaistnienie i rozwój opresjonowanego upodmiotawiania, a więc powstanie i osiąganie coraz wyższych poziomów podmiotowości politycznej przez wielkie grupy społeczne, które jednak nie są włączone do systemu politycznego. Wyznacznikiem punktu siodłowego jest moment rozpoczęcia procesów kreacji opresjonowanego upodmiotawiania. Warunkiem niezbędnym jest natomiast jego późniejsze, trwałe istnienie, niezależnie od skali jego powszechności.

Warto podjąć próbę sformułowania modelu teoretycznego opresjonowanego upodmiotawiania. Przede wszystkim należy stworzyć typologie stanów pośrednich między typem idealnym uprzedmiotowienia a upodmiotowienia politycznego wielkich grup społecznych. Konieczne jest w tym przypadku, zgodnie z podstawowymi kryteriami tworzenia klasyfikacji ${ }^{8}$, stworzenie skali pomiaru na continuum między uprzedmiotowieniem a upodmiotowieniem politycznym. W tym celu warto wykorzystać, po pierwsze, poziomy tak zwanej analizy schwache Interessen (ang. weak interests) zastosowane w pracach niemieckich politologów ${ }^{9}$. Po drugie, niezbędne jest utworzenie dla każdego typu lokalnej i globalnej bifurkacji trajektorii rozwoju opresjonowanego upodmiotawiania, począwszy od punktu siodłowego aż do momentu rewolucyjnego. Możliwe jest w konsekwencji sformułowanie kilku założeń dotyczących przebiegu procesu bifurkacji niedemokratycznych reżimów politycznych:

1. Punkt siodłowy może być zdefiniowany jako początek zaistnienia zjawiska opresjonowanego upodmiotawiania i od tego momentu rozpoczyna się proces nabywania podmiotowości wielkich grup społecznych poza klasą rządzącą. Nie oznacza to jednak ujawnienia się w pełni upodmiotowionych wielkich grup społecznych na scenie politycznej.

2. Pomiędzy powstaniem stanu opresjonowanego upodmiotawiania a przekroczeniem punktu krytycznego (wybuchu rewolucji lub implozji) istnieje stan chwiejnego equilibrium o coraz większej amplitudzie zmienności i odmienności od istotnościowych cech danego reżimu.

7 Zob. np. V.S. Anishchenko, T. Vadivasova, G. Strelkova, Deterministic Nonlinear Systems, Cham 2014.

${ }^{8}$ J. Rak, Theorizing Cultures of Political Violence in Times of Austerity: Studying Social Movements in Comparative Perspective, New York-London 2018.

9 T. Von Winter, U. Willems, Die politische Repräsentation schwacher Interessen: Anmerkungen zum Stand und zu den Perspektiven der Forschung, [w:] Politische Repräsentation schwacher Interessen, red. T. Von Winter, U. Willems, Wiesbaden 2000, s. 9-36; Politische Repräsentation..., Wiesbaden 2013. 
3. Wybuch rewolucji lub implozja mogą być definiowane jako załamanie dotychczas istniejącego stanu chwiejnego equilibrium.

Wcześniej zostały zarysowane elementarne siatki kategorii teoretycznych oraz założeń dotyczących procesu bifurkacji. Był to warunek konieczny przed sformułowaniem hipotez i opracowaniem narzędzi badawczych. Do najważniejszych hipotez można zaliczyć:

1. Od momentu przekroczenia punktu siodłowego do czasu załamania się reżimu politycznego chwiejne equilibrium ma coraz większy poziom skokowo zwiększającej się niestabilności.

2. Opresjonowane upodmiotawianie jest procesem nieciągłym na poziomie artykulacji i struktur organizacyjnych pełniących zastępczo funkcje reprezentacji. Po przekroczeniu progu agregacji interesów i potrzeb jest to proces ciągły.

3a. Znaczące impulsy opresywne opóźniają procesy upodmiotawiania, jednakże najpóźniej po zmianie pokoleniowej procesy te są kontynuowane.

3b. Pojawienie się takiego impulsu powoduje, że procesy upodmiotawiania dochodzą do wyższego poziomu podmiotowości politycznej niż w przypadku niezaistnienia takiego impulsu.

4. Czas trwania procesu nabywania podmiotowości wielkich grup społecznych jest zależny zarówno od zasobów społecznych będących w ich posiadaniu, jak i od skuteczności polityki niedopuszczania do ich wykorzystywania, prowadzonej przez rządzące grupy społeczne.

5. Każdy proces bifurkacji danego niedemokratycznego reżimu w społeczeństwach masowych jest niepowtarzalny. Każdy z nich, ze względu na charakterystyczne cechy swojego przebiegu, może jednak zostać prawdopodobnie zaklasyfikowany do jednego ze znanych w literaturze, już wymienionych, typów lokalnej bądź globalnej bifurkacji.

\section{Metodologia badań}

Cechy istotnościowe społeczeństw zamkniętych oraz kompatybilnych z nimi reżimów niedemokratycznych zmuszają do przyjęcia następującego podstawowego założenia epistemologicznego przed określeniem metodyki badania:

1. Procesy nabywania podmiotowości są zmienną obserwowalną pośrednio, a tym samym są trudno dostrzegalne $\mathrm{w}$ wypadku prowadzenia badań opartych na metodzie sondażu. Nie sposób też przenosić do badania reżimów niedemokratycznych technik badawczych stosowanych przy badaniu reżimów demokratycznych.

Warto w tym przypadku zastosować technikę analizy zawartości/treści źródeł urzędowych wytworzonych przez policje polityczne oraz technikę analizy zawartości/treści źródeł pisanych, oralnych i typowych dla twórczości ludowej. Dotyczy to przede wszystkim badań w kwestii przejawów nonkonformizmu politycznego jako zewnętrznego objawu procesów upodmiotawiania. Warto też dokonać analizy wtórnej opracowań na temat poszczególnych aspektów procesów upodmiotawiania. W miarę dobrze zostały 
opracowane na przykład kwestie dotyczące plotek, legend i humoru politycznego ${ }^{10}$ oraz artykulacji petycyjnej ${ }^{11}$. Wskazane techniki badawcze tworzą ramy do stworzenia odpowiednich narzędzi badawczych dotyczących poszczególnych poziomów i płaszczyzn zjawiska opresyjnego upodmiotawiania.

Sformułowanie narzędzi badawczych oraz dobór próby badawczej pozwalają na przeprowadzenie analizy empirycznej. Rezultaty tej ostatniej pozwolą na chociażby częściowe zweryfikowanie postawionych hipotez oraz sprawdzenie, jaki jest poziom eksploracyjny teorii bifurkacji. Test empiryczny pozwoli/zmusi z bardzo dużym prawdopodobieństwem do dokonania odpowiednich modyfikacji lub uzupełnień tej teorii. Najbardziej prawdopodobnym scenariuszem jest kreacja nowych typów bifurkacji - jeszcze nieodkrytych przez matematyków zajmujących się systemami dynamicznymi.

\section{Casus PRL-u czasów Edwarda Gierka}

Polska po przejęciu władzy przez Edwarda Gierka w grudniu 1970 roku zaczęła się prędko modernizować. Był to rezultat wdrażania technokratycznego modelu rozwoju gospodarki oraz ekspansywnego kopiowania zachodnich technologii. Bardzo szybki wzrost poziomu inwestycji, próby upaństwowienia choćby części produkcji rolnej i ekspansja przemysłu ciężkiego przy centralnie sterowanej gospodarce spowodowały pojawienie się już w 1974 roku znacznych niedoborów rynkowych ${ }^{12}$. Przez następne dwa lata system społeczno-gospodarczy na zewnątrz był niezmienny. Tymczasem narastało oddolne niezadowolenie z gromadzących się trudności życia codziennego. Coraz dłuższe kolejki do sklepów mięsnych, potem spożywczych, ze sprzętem gospodarstwa domowego i meblowym to niejedyna przyczyna. O wiele ważniejsze jest narastanie rozdźwięku między aspiracjami materialnymi a możliwościami ich zaspokojenia. W latach 1974-1976 następowało przemieszczanie się przez punkt siodłowy (saddle point).

Podwyżka cen urzędowych na towary żywnościowe w czerwcu 1976 roku (na przykład chleba o 50\%) wywołała powszechne strajki i demonstracje uliczne, z których najbardziej znane są demonstracje w Radomiu i strajk w zakładach produkujących traktory ursus ${ }^{13}$. Postąpiono zgodnie z logiką systemu. Mimo ogromnej nierównowagi między podażą a popytem nie sposób było uwolnić cen. Nie sposób też było wprowadzać stopniowo podwyżek cen towarów, gdyż aparat zarządzania gospodarką nie był na to przygotowany. Jednakże decyzja zgodna z logiką systemu spowodowała skutki groźne dla jego

10 J. Best, Fashion, Topical Jokes, and Rumor as Short-Term Enthusiasms, „Rumor Mills: The Social Impact of Rumor and Legend" 125, 2017.

11 Political Representation, red. I. Shapiro et al., Cambridge 2010, szczególnie artykuł M. Knights, Participation and representation before democracy: Petitions and addresses in premodern Britain, s. 35-57.

12 Z. Landau, Etapy rozwoju Polski Ludowej, „Przegląd Historyczny” 78, 1987, nr 2, s. 211-253; P. Jachowicz, Polska w kryzysie zadłużeniowym, „Kwartalnik Kolegium Ekonomiczno-Społecznego Studia i Prace/Szkoła Główna Handlowa” 2011, nr 3, s. 89-104.

13 P. Sasanka, Czerwiec 1976. Geneza - przebieg - konsekwencje, Warszawa 2006; M. Zaremba, Upalny czerwiec 1976, „Więź” 44, 2001, nr 6. 
całokształtu. Groźba wybuchu żywiołowego i powszechnego buntu społecznego była tak duża, że ekipa Gierka zdecydowała się zrezygnować z podwyżki cen i jednocześnie represjonować protestujących. Następnie wprowadzono kartki na cukier oraz zaczęto otwierać sklepy z towarami powszechnie dostępnymi, ale po znacznie wyższych cenach. Osiągnięto równowagę, jednakże na zupełnie innym poziomie.

Konsekwencją tak zwanych wydarzeń radomskich było powstanie zorganizowanej opozycji demokratycznej, której głównym zadaniem była obrona robotników przed represjami. Kolejne cele dotyczyły uzyskania jak największego możliwego poziomu niezależności i podmiotowości przez naród. Środkiem do tego celu była samoorganizacja („Nie palcie komitetów, zakładajcie własne” - mówił Jacek Kuroń) ${ }^{14}$. Opozycja demokratyczna dążyła do przejścia od etapu żywiołowości (anomiczności ruchu społecznego) do tworzenia reprezentacji narodu politycznego. Konsekwencją przetrwania systemu było zatem powstanie struktur opozycyjnych, które starały się doprowadzić do anihilacji monistycznego systemu politycznego. Equlibrium polityczne stało się chwiejne.

Od ostatniego dnia grudnia 1978 do lutego 1979 roku trwała w Polsce zima stulecia. Przez kilka tygodni nie działała komunikacja kolejowa i autobusowa, obawiano się o dostawy żywności i opału do miast ${ }^{15}$. Państwo nie było w stanie zagwarantować realizacji podstawowych potrzeb. PRL straciło opinię podmiotu zdolnego do zaspokojenia elementarnych potrzeb o charakterze wegetatywnym.

W 1978 roku konklawe wybrało krakowskiego kardynała Karola Wojtyłę na papieża. Przybrał on imię Jan Paweł II. Jego pierwsza pielgrzymka do Polski odbyła się w czerwcu 1979 roku. W każdym z nabożeństw uczestniczyło co najmniej kilkaset tysięcy osób ${ }^{16}$. Polacy doświadczyli masowego zbiorowego i pokojowego współdziałania bez udziału państwa.

Te dwa procesy można potraktować jako bardzo silne czynniki osłabiające system polityczny. Każdy z nich może zostać zaliczony do bodźców dezintegrujących system (repellor). W pierwszym przypadku nastąpiło znaczące osłabienie poziomu akceptacji systemu ze względu na jego niesprawność. W drugim zaś pojawiło się zbiorowe doświadczenie samoorganizacji, a więc jednej z podstawowych cech podmiotowości każdej grupy społecznej.

W marcu 1980 roku odbyło się głosowanie na jedną listę do Sejmu PRL. Opozycja demokratyczna ogłosiła bojkot tego rodzaju manifestacji poparcia dla partii rządzącej. $\mathrm{W}$ dużych miastach frekwencja była znacząco niższa niż w latach poprzednich ${ }^{17}$. Co prawda wyniki urzędowe nie odbiegały od poprzednich, ale znacząca część ludności (głównie miejskiej) nabyła nowe doświadczenie. Możliwe było powstrzymanie się od

14 A. Friszke, Czas KOR-u. Jacek Kuroń a geneza Solidarności, Kraków 2011.

15 M. Zaremba, Zimno, ciepło, gorąco. Nastroje Polaków od „zimy stulecia” do lata 1980, 2013, http:// docplayer.pl/12302152-Zimno-cieplo-goraco-nastroje-polakow-od-zimy-stulecia-do-lata-80.html (dostęp: 15.04.2021).

16 Ł. Kamiński, PZPR wobec pielgrzymki Jana Pawła II do Ojczyzny w 1979 roku, „Biuletyn Instytutu Pamięci Narodowej” 2002, nr 7.

17 M. Siedziako, Wybory do Sejmu PRL w latach 1952-1985, „Dzieje Najnowsze” 48, 2016, nr 4, s. 161171. 
manifestacyjnego popierania PZPR i jej kierownictwa przy jednoczesnym braku reakcji ze strony rządzących. Mechanizmy kontroli społecznej wymuszające zachowania zgodne z potrzebami stabilizowania systemu nie zadziałały. Przestał działać jeden z najsilniejszych bodźców stabilizujących całość polityczną (attractor), wymuszający odpowiedni poziom konformizmu społecznego.

1 lipca 1980 roku rozpoczynają się strajki w fabrykach na Lubelszczyźnie. Wiecujący pracownicy żądają podwyżek pensji i je otrzymują. Ci, którzy nie strajkują, podwyżek nie otrzymują ${ }^{18}$. Taki był utrwalony przez ekipę Gierka mechanizm postępowania, bardzo skuteczny w przypadku istnienia całkowitej blokady komunikacyjnej. Jednakże ta ostatnia w skali lokalnej przestaje działać. W konsekwencji strajki przemieszczają się przez cały kraj: 14 sierpnia wybucha strajk w Stoczni Gdańskiej, dwa dni później — mimo zawartego porozumienia o podwyżce płac - przekształca się on w strajk solidarnościowy z innymi strajkującymi zespołami pracowniczymi Trójmiasta. Powstaje Międzyzakładowy Komitet Strajkowy, który formułuje listę żądań, znaną jako „21 postulatów”. Najważniejszym z nich jest utworzenie niezależnych od rządzącej partii i samorządnych związków zawodowych ${ }^{19}$. Podpisanie porozumień gdańskich, następnie szczecińskich i w Jastrzębiej Górze oznacza zakończenie strajków okupacyjnych w skali całego kraju. Ekipa przejmująca władzę w PZPR po Edwardzie Gierku uniknęła strajku generalnego i jednocześnie nieprzewidywalnej reakcji Kremla. Ten z kolei zgodził się na takie rozwiązanie, wiedząc, że każde inne zmusza do użycia ogromnych zasobów, przy czym ostateczny efekt jest niezbyt pewny.

W rezultacie system monistyczny charakterystyczny dla totalitaryzmu przestał istnieć. Rozpoczęły się bardzo szybkie procesy samokreacji społeczeństwa obywatelskiego, a inaczej - nabywania podmiotowości politycznej przez ogromną część polskiego społeczeństwa. System przetrwał, ale odbyło się to kosztem akceptacji zaniku jego najistotniejszych cech. Bifurkacja lokalna w ramach sowieckiego imperium została zakończona. Osiągnięto nowe, wyjątkowo chwiejne equilibrium, ale dotyczyło to już zupełnie innego pod względem istotnościowym systemu politycznego.

\section{Konkluzja}

Przedstawiona analiza skłania do sformułowania kilku wniosków. Po pierwsze niemożliwe (albo bardzo trudne) jest uchwycenie konkretnego, umiejscowionego w czasie punktu siodłowego (saddle point). Możliwe jest tylko wychwycenie, mniej lub bardziej dokładnie, początku i końca okresu przechodzenia od rozwoju i stabilizacji do bifurkacji.

Po drugie czynniki dezintegrujące (repellors) mają rozmaity charakter. Mogą to być bodźce zewnętrzne niezależne od systemu. Mogą też wynikać z nieefektywności samego systemu. Najbardziej warte zbadania są jednak te czynniki, które są stosowane zgodnie z logiką systemu. W sytuacjach podobnych do poprzednich, ale o zmienionych i niezbyt

18 M. Homa, Strajk lubelskich kolejarzy w lipcu 1980 r., „Biuletyn Instytutu Pamięci Narodowej” 2002, nr 12 (23), s. 21-27.

19 A. Machcewicz, Bunt. Strajki w Trójmieście. Sierpień 1980, Gdańsk 2015. 
jasnych parametrach ich zastosowanie powoduje nieoczekiwane rezultaty. Część z tych reakcji ośrodka decyzyjnego może wynikać również z nieumiejętności samouczenia się systemu, a więc braku zdolności do modyfikacji mechanizmów działania nawet wtedy, gdy już wcześniej nie były one efektywne.

Po trzecie czynniki integrujące (attractors) w okresie bifurkacji są coraz słabsze i coraz mniej skuteczne. Wynika to nie tylko ze zmniejszenia się zasobów materialnych, ale też z narastającego dystansu do odgrywanych ról społecznych przez funkcjonariuszy systemu oraz zmniejszającego się poziomu konformizmu wśród mas społecznych.

Jakie są warunki stosowalności teorii bifurkacji reżimów niedemokratycznych społeczeństw masowych do innych typów społeczeństw oraz reżimów politycznych? Jakie warunki muszą zostać spełnione, aby tego typu teoria mogła być zastosowana w przypadku reżimów niedemokratycznych w społeczeństwach informatycznych? Choć literatura na ten temat jest niezbyt bogata ${ }^{20}$, $\mathrm{z}$ powodu znaczenia tego zagadnienia warto jednak przeprowadzić taką próbę. Zadaniem jeszcze bardziej skomplikowanym może być zbadanie, w jakim stopniu teoria bifurkacji oparta na modelu opresjonowanego upodmiotawiania może być zastosowana do badania kryzysów politycznych w reżimach demokratycznych.

\section{Bibliografia}

Anishchenko V.S., Vadivasova T., Strelkova G., Deterministic Nonlinear Systems, Cham 2014.

Bäcker R., Totalitaryzm w cywilizacji informatycznej, „Studia nad Autorytaryzmem i Totalitaryzmem” 39, 2017, nr 1, s. 9-18.

Best J., Fashion, Topical Jokes, and Rumor as Short-Term Enthusiasms, „Rumor Mills: The Social Impact of Rumor and Legend" 125, 2017, s. 173-188.

Friszke A., Czas KOR-u. Jacek Kuroń a geneza Solidarności, Kraków 2011.

Goldstone J.A., Toward a Fourth Generation of Revolutionary Theory, „Annual Review of Political Science” 4, 2001, nr 1, s. 139-187.

Homa M., Strajk lubelskich kolejarzy w lipcu 1980 r., „Biuletyn Instytutu Pamięci Narodowej” 2002, nr 12 (23), s. 21-27.

Jachowicz P., Polska w kryzysie zadłużeniowym, „Kwartalnik Kolegium Ekonomiczno-Społecznego Studia i Prace/Szkoła Główna Handlowa" 2011, nr 3, s. 89-104.

Jennings W., Stoker G., The Bifurcation of Politics: Two Englands, „The Political Quarterly” 87, 2016, nr 3, s. 372-382.

Kamiński Ł., PZPR wobec pielgrzymki Jana Pawła II do Ojczyzny w 1979 roku, „Biuletyn Instytutu Pamięci Narodowej" 2002, nr 7, s. 39-42.

Khan Q.J.A., Hopf Bifurcation in Multiparty Political Systems with Time Delay in Switching, „Applied Mathematics Letters" 13, 2000, nr 7, s. 43-52.

Landau Z., Etapy rozwoju Polski Ludowej, „Przegląd Historyczny” 78, 1987, nr 2, s. 211-253.

Leonov G.A., Kudryashova E.V., Kuznetsov N.V., Modeling and Identification of the Tunisian Social System in 2011-2014: Bifurcation, Revolution, and Controlled Stabilization, „IFAC-PapersOnLine” 48, 2015, nr 11, s. 725-729.

20 Zob. R. Bäcker, Totalitaryzm w cywilizacji informatycznej, „Studia nad Autorytaryzmem i Totalitaryzmem” 39, 2017, nr 1, s. 9-18; S.S. Wolin, Inverted Totalitarianism, „Nation” 276, 2003, nr 19, s. 13; idem, Democracy Incorporated: Managed Democracy and the Specter of Inverted Totalitarianism, Princeton-Oxford 2017. 
Machcewicz A., Bunt. Strajki w Trójmieście. Sierpień 1980, Gdańsk 2015.

Political Representation, red. I. Shapiro, S.C. Stokes, E.J. Wood, A.S. Kirshner, New York 2010.

Politische Repräsentation schwacher Interessen, red. U. Willems, T. Winter, Wiesbaden 2013.

Rak J., Theorizing Cultures of Political Violence in Times of Austerity: Studying Social Movements in Comparative Perspective, New York-London 2018.

Rao G.G., Hyderabad and the Bifurcation of Andhra Pradesh, „Economic \& Political Weekly” 2013, nr 48 (42), s. 34-41.

Sasanka P., Czerwiec 1976. Geneza - przebieg - konsekwencje, Warszawa 2006.

Schmidt B.C., Political Discourse of Anarchy: A Disciplinary History of International Relations, New York 2016.

Seeds C., Bifurcation Nation: Strategy in Contemporary American Punishment, 2015, https://papers.ssrn. com/sol3/papers.cfm?abstract_id=2613083.

Siedziako M., Wybory do Sejmu PRL w latach 1952-1985, „Dzieje Najnowsze” 48, 2016, nr 4, s. 161-171.

Skocpol T., Theda S., States and Social Revolutions: A Comparative Analysis of France, Russia and China, Cambridge 1979.

Von Winter T., Willems U., Die politische Repräsentation schwacher Interessen: Anmerkungen zum Stand und zu den Perspektiven der Forschung, [w:] Politische Repräsentation schwacher Interessen, red. U. Willems, T. Winter, Wiesbaden 2000, s. 9-36.

Wallerstein I., The Modern World-System and Evolution, „Journal of World-Systems Research” 1, 1995, nr 1, s. 512-522.

Wallerstein I., The Time of Space and the Space of Time: The Future of Social Science, „Political Geography” 17, 1998, nr 1, s. 71-82.

Wallerstein I., World-System Analysis: Theoretical and Interpretative Issues, [w:] T.K. Hopkins, I. Wallerstein, World-System Analysis: Theory and Methodology, Beverly Hills 1982, s. 91-103.

Wolin S.S., Democracy Incorporated: Managed Democracy and the Specter of Inverted Totalitarianism, Princeton-Oxford 2017.

Wolin S.S., Inverted Totalitarianism, „Nation” 276, 2003, nr 19, s. 13-23.

Zaremba M., Upalny czerwiec 1976, „Więź” 44, 2001, nr 6, https://wiez.pl/2001/01/01/1213-upalny-czerwiec-1976/.

Zaremba M., Zimno, ciepło, gorąco. Nastroje Polaków od „zimy stulecia” do lata 1980, 2013, http://docplayer. pl/12302152-Zimno-cieplo-goraco-nastroje-polakow-od-zimy-stulecia-do-lata-80.html.

\section{Bifurcation of non-democratic regimes of mass-societies: Poland's case in times of Edward Gierek}

Keywords: bifurcation, political monism, repellers, Poland, Edward Gierek

\section{Summary}

The breakdown of political structures is a process developing from the saddle point to the revolution or implosion of a political system. The decay process is determined on the one hand by the strength of the influence of stabilizing factors (attractors) and, on the other hand - by the repellers. In Poland, under Edward Gierek, the saddle point was achieved in 1974-1976, and then the process of disintegration began. The most important moments of revealing the repellers were: social protests against price increases in June 1976, "the winter of the century" in 1978/1979, the papal pilgrimage in 1979, parliamentary elections in March 1980, and the July 1980 strikes. The August and September 1980 agreements ended the process of disintegration of the monistic political system in Poland. 